http://www.jfas.info

\title{
ASSESSMENT OF WATER QUALITY STATUS USING UNIVARIATE ANALYSIS AT KLANG AND JURU RIVER, MALAYSIA
}

M. S. M. Zin ${ }^{1}$, H. Juahir ${ }^{1}{ }^{*}$, M. E. Toriman ${ }^{2}$, M. K. A. Kamarudin ${ }^{1}$, N. A. Wahab ${ }^{1}$ and A. Azid ${ }^{1}$

${ }^{1}$ East Coast Environmental Research Institute (ESERI), Universiti Sultan Zainal Abidin, Gong Badak Campus, 21300 Kuala Nerus, Terengganu, Malaysia

${ }^{2}$ School of Social, Development and Environmental Studies, Faculty of Social Sciences and Humanities, National University of Malaysia, 43600 Bangi, Selangor, Malaysia

Published online: 08 August 2017

\begin{abstract}
Klang River and Juru River which today suffers from water quality problems resulting from anthropogenic and geomorphology factors. The purpose of this study was to assess the water quality status from 2009 until 2013. 10 monitoring stations covering along Klang River and Juru River were selected. Six water quality parameters analyzed based on in-situ and ex-situ analysis were carried out according to the univariate analysis to obtain WQI level. The result indicated the impact of various anthropogenic and geomorphology activities contributed higher values of $\mathrm{BOD}, \mathrm{COD}, \mathrm{SS}$ and $\mathrm{NH}_{3}-\mathrm{NL}$ but the TSS concentration contamination at Juru River still on stable condition. Downstream and middle stream more polluted than upstream area triggered by pollutants from waste products of development activities, which inclusion of a high amount of pollutants of Klang River and Juru River.
\end{abstract}

Keywords: water quality; univariate analysis; national water quality standards (NWQS); anthropogenic.

Author Correspondence, e-mail: hafizanjuahir@unisza.edu.my doi: http://dx.doi.org/10.4314/jfas.v9i2s.7 


\section{INTRODUCTION}

River ecosystems are most important in life to humans and other living things in earth. In Malaysian, the river contributes more than $90 \%$ for supply of raw water in domestic sector, agriculture, industry and other development. Within the previous few decades, the accelerated pace of commercial development and progressive growth of population caused in tremendous increase within the demand of water. Water demand in the domestic industry and other industries are expected to increase by $63 \%$ from 2000 until 2050. From 2005 to 2009, the total supply of raw water taken directly from the river showed an increase to $23.9 \%$ and the utilization rate is estimated to be increasing from year to year.

Based on the Environmental annual report issued by the Department of Environment (DOE), the river is one of main sources in a country which has many uses [1-2]. Thus, the river is also as a valuable natural heritage which must be constantly maintained and preserved for the purposes of the guarantee continued supply of clean water in the future. The history of Malaysian proved human settlements were built around the river basin [3-4]. After Malaysian gained independence, the village profile originating village has been turned into the town or city. Land use development around the river basin also continues growth rapidly by carrying out a variety of patterns current land use. Unsustainable water quality is one of the problems related to water and rivers that has become a very big issue today.

Currently, the quality aspect of water is ignored, and many reservoirs and rivers became polluted with the introduction of human settlements and activities in water-producing areas. The bad impact, the water deterioration issues increasing once the agricultural which conducting as large scale such as rubber and oil palm plantation since 1970s. Besides that, the development of manufacturing industries such as electronics, textiles and chemicals through 1980 give negative impact to the water quality [5]. The land use pattern showed allocated land area (hectares) larger in subsequent years, for example for the agricultural sector was increased from 5.9 million hectares to 6.4 million hectares from 2000 to 2005 [6].

Water is the source of all biotic and abiotic lives. Water for different purposes has its own requirements for the composition and purity and each body of water has to be analyzed on a regular basis to confirm the suitability. Water is the most important for sustaining life and 
resource in all economic activities associated with agriculture and industry. Water quality index (WQI) is useful in assessing the suitability of river waters for a variety of uses such as agriculture, aquaculture, and domestic use. From the measurement of WQI indicates that the rivers in Malaysia suffered from severe pollution due to the deterioration of water quality parameters in the long term. Mostly research studies conducted found that a lot of river triggers water pollution problems caused by anthropogenic factors such as domestic sewage, industrial, agricultural and livestock into river drainage [7-9]. However, there are issues of water quality deterioration are due from natural resources in the event of extreme floods or droughts [10-11].

Almost every year the river basin was reported polluted with higher numbers such as 7 polluted of river basin in 1998 and 16 polluted of river basin in 2008 [12], and is expected to be increased in the long term. This problem brings disadvantages to living organisms and it is not suitable for any requirement and affect human health. This study proposed to identify the distribution and changes in water quality level at Klang River and Juru River. Malaysia has over 1000 manual and automatic river water quality monitoring stations in 146 basins maintained by the Department of Environment (DOE) alone [13]. These exclude other stations maintained by other agencies such as the Department of Irrigation and Drainage (DID) as well as the respective state level agencies. The primary method employed to classify the river water quality monitored by NWQS which a set of standards derived based on beneficial uses of water. The measurements of WQI carried out using WQI parameters such as DO, BOD, COD, $\mathrm{SS}, \mathrm{pH}$ and $\mathrm{NH}_{3} \mathrm{NL}$ to show the class and specific water consumption. The water quality study was conducted at the same time can take action in applying river planning towards more sustainable.

\section{METHODOLOGY}

Klang River is one of the most important rivers in Malaysia where it is in Klang Valley which has a denser river in the Territory of Kuala Lumpur (WPKL) and flows directly through the major cities such as Kuala Lumpur, Shah Alam, Petaling Jaya and Klang. Klang River approximately about $120 \mathrm{~km}$ length which covers a total catchment area of $1288 \mathrm{~km}$, 
(N03010'07.2 and E101042'32.8). The area has a position at the confluence of the Klang Straits which lies the town of Westport. In the middle of the river consists of residential areas such as Kg. Padang Jawa, Kg. Seri Puchong, Taman Seputeh, Kg. Baru Taman Melawati and industrial park in Shah Alam, Klang and Ampang including the business district and services such as Mid Valley, KL Sentral, KL Tower and KLCC and Hulu Sungai Klang begins in Titiwangsa Mountain Range bordering Pahang. Klang River connected to Gombak River in Kuala Lumpur and faced huge threats from various sources over ten years ago due to various types of industrial activities such as food and beverages, chemical manufacturing, semi-conductor, electrical and automotive. The river flow through a heavily populated like Klang River are commonly associated with point and non-point sources, therefore it is difficult to trace the loading of pollutants in the river [14-15]. A total of 8 sampling stations have been selected $(1 \mathrm{~K} 01,1 \mathrm{~K} 05,1 \mathrm{~K} 06,1 \mathrm{~K} 07,1 \mathrm{~K} 08,1 \mathrm{~K} 25,1 \mathrm{~K} 40$ and $1 \mathrm{~K} 46)$ (Table 1). All the stations represented three sub area of the river downstream, midstream and upstream of Klang River. 1K01 (Port Klang), 1K05 (Jln. HICOM-Toll Puchong), 1K06 (Petaling Bahagia), 1K07 (Bangunan Sultan Sulaiman), 1K08 (Jln. Dang Wangi), 1K25 (Mid Valley, Abdullah Hukum), 1K40 (Bulatan Syed Putra) and 1K46 (Kg. Datuk Keramat, Hulu Kelang) (Table 1). Juru River is located on the Northwest coast of Peninsular Malaysia, in the state of Penang and within a coastal mudflat in the Juru and Bukit Tambun district about 7.95 kilometers at U05019'91.7 and S100026'70.4. Juru River drainage involves a small part in the Seberang Perai Tengah (SPT) (Fig. 1). The physical environment of the confluence of the rivers is the Prai Industrial area while at the headwaters of the houses located near Bukit Mertajam like Kampung Paya, Kampung Desa Wawasan, Kampung Tanah Liat, Taman Suria Aman and Taman Berapit. There are two sampling stations have been covered 2JR01 and 2JR12 in this study (Table 1) represent areas with downstream and upstream. 2JR01 (Perindustrian Perai Area) and 2J12 (Kampung Tanah Liat) which are located adjacent to industrial areas which were reclaimed from mangrove. The types of industry presently in operation include electronics, textiles, basic and fabricated metal products, food processing and canning, processing of agricultural products, feed mills, chemical plants, rubber based industry, timber based wood products, paper products and printing works, and transport equipment. Other 
main activities that are operating in environment of the culture area are ships' harbor with petroleum unloading and a red earth quarry which extends right up to the coastline areas [16].

Table 1. DOE sampling stations at Klang River and Juru River

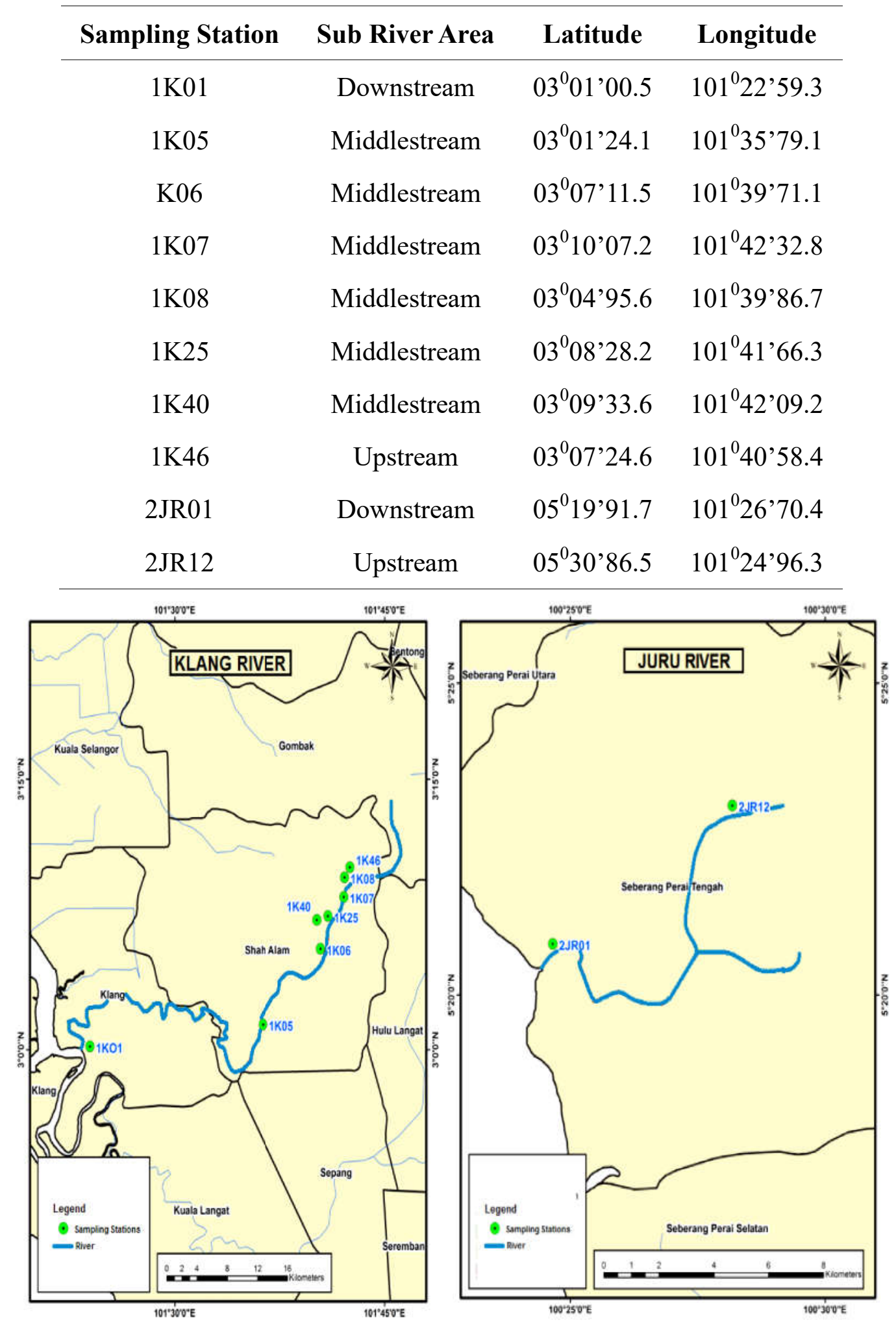

Fig.1. Location map of Klang River and Juru River, Malaysia 
Water sampling at Klang River and Juru River was conducted from 2009-2013 to get primary data and secondary data obtained from the Department of Environment (DOE). The measurement of WQI for Klang River and Juru River monitored by NWQS which a set of standards derived based on beneficial uses water. In Malaysian, six of water quality parameters set by the DOE used to demonstrate the class and usefulness of water according to the NWQS. Six water quality parameters measured parameter is composed of DO, BOD, $\mathrm{COD}, \mathrm{SS}, \mathrm{pH}$ and $\mathrm{NH}_{3} \mathrm{NL}$ with water samples collected at stations representing the related sampling. Next, the average value of the WQI for the six parameters obtained by running the univariate analysis through software Startplus as measured by the NWQS in accordance with the requirements of DOE (Table 2) [17]. All the water samples from ten stations were stored in the refrigerator at the temperature less than $6^{\circ} \mathrm{C}$ with covered layer to maintain dark condition. The overall laboratory analysis was completed within 14 days from the date of sample collection to analysis COD and TSS. The others measurements of in situ parameters were $\mathrm{pH}, \mathrm{NH} 3-\mathrm{NL}, \mathrm{DO}$ and BOD. All of these parameters were determined by using the water-quality Multiprobe Model DO meter YSI 58 and BOD check portable. This multiprobe meter was calibrated before field sampling. Laboratory analysis for COD and TSS was performed based on the standard method of analysis (APHA 1998) procedure. The Gravimetric method used to analysis TSS parameter which measured in $\mathrm{mg} / \mathrm{L}, 250 \mathrm{ml}$ water sample was needed for each station. Firstly, weighing the membrane filters using electronic weighing, then a membrane filter was placed onto a filtration apparatus (Nalgene, U.S.A) which connected to a vacuum pump and clipped in place. The $250 \mathrm{ml}$ river water sample lowly poured into the filtration jar, the membrane filter was removed and allowed to dry in the drying jar (Fig. 2). Once the membrane filter paper is dried, it is weighed to get the reading. TSS is measured by $\mathrm{mg} / \mathrm{L}$ unit based on equation. Precisely precaution steps should be taken when the river water sample were taken because the interference of the river water flow should be minimum to avoid deposition of the measured suspended sediment. This study used the univariate analysis to explain on the average value of WQI. Fig. 3 showed the framework for measurement of WQI based on univariate analysis.

$\mathrm{SS}=\{(\mathrm{WBF}+\mathrm{DR})-\mathrm{WBF}\}(\mathrm{mg}) \times 1000 / \mathrm{VFW}(\mathrm{mL})$ 
$=\mathrm{mg} / \mathrm{L} / 1000 / 1000 / 1000$

$=$ tonne $/ \mathrm{L}$

$* \mathrm{WBF}=$ Weight of membrane filter; $\mathrm{DR}=$ Dry residue; VFW $=$ Volume of filtered water [18]

Table 2. National Water Quality Standards (NWQS) for Malaysia [13]

\begin{tabular}{cccccrrrr}
\hline Parameter & Unit & \multicolumn{7}{c}{ Class } \\
& & I & IIA & IIB & III & IV & V \\
DO & $\mathrm{mg} / \mathrm{L}$ & 7.0 & $5.0-7.0$ & $5.0-7.0$ & $3.0-5.0$ & $<3.0$ & $<1.0$ \\
$\mathrm{BOD}$ & $\mathrm{mg} / \mathrm{L}$ & 1.0 & 3.0 & 3.0 & 6.0 & 12.0 & $>12.0$ \\
$\mathrm{COD}$ & $\mathrm{mg} / \mathrm{L}$ & 10.0 & 25.0 & 25.0 & 50.0 & 100.0 & $>100$ \\
$\mathrm{TSS}$ & $\mathrm{mg} / \mathrm{L}$ & 25.0 & 50.0 & 50.0 & 150.0 & 300.0 & 3.00 \\
$\mathrm{pH}$ & & $6.5-8.5$ & $6.0-9.0$ & $6.0-9.0$ & $5.0-9.0$ & $5.0-9.0$ & - \\
$\mathrm{NH}_{3}-\mathrm{NL}$ & $\mathrm{mg} / \mathrm{L}$ & 0.1 & 0.3 & 0.3 & 0.9 & 2.7 & $>2.7$ \\
\hline
\end{tabular}

Description of WQI [13]

\begin{tabular}{cl}
\hline Class & \multicolumn{1}{c}{ Water Usage } \\
\hline I & - Preservation of the natural environment \\
IIA & - The water supply I-for not need treatment \\
IIB & - Fishery I-for highly sensitive aquatic species \\
III & - Supply water II-require conventional treatment \\
IV & - Fishing II-for sensitive species \\
V & - Suitable for recreational activities involving bodily contact \\
\hline
\end{tabular}

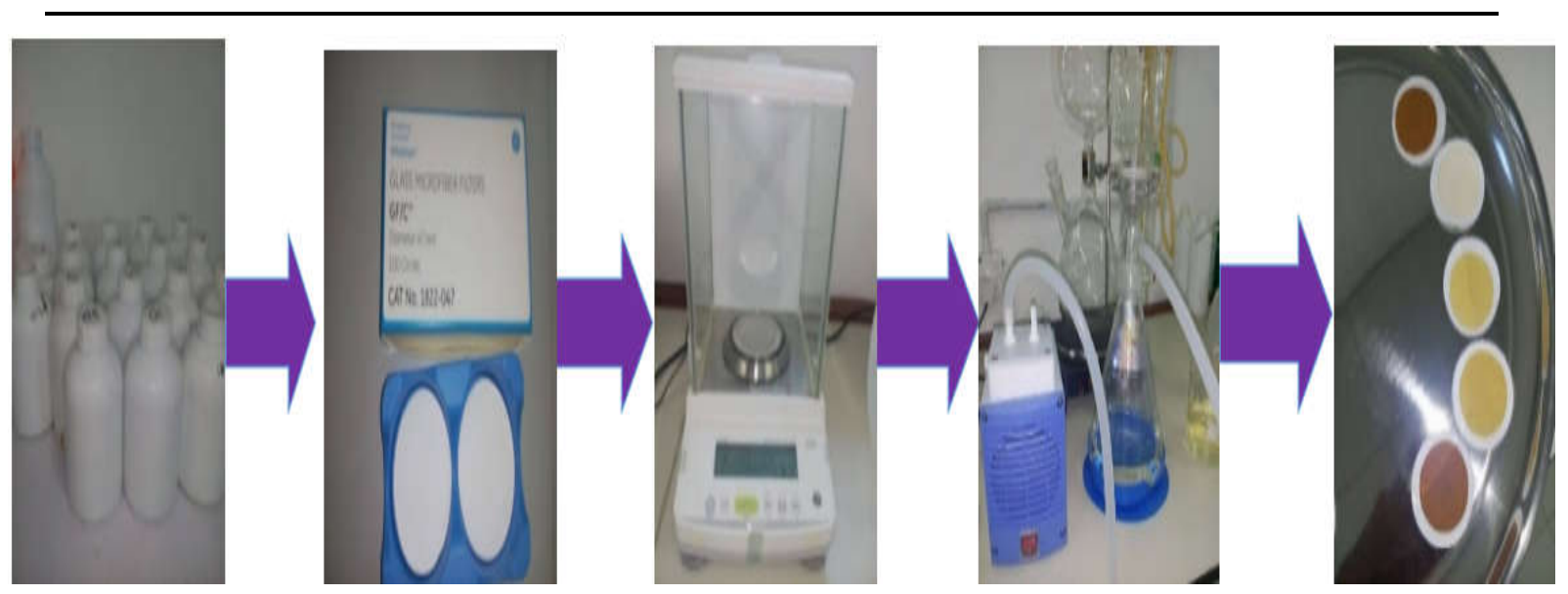

Fig.2. a) Sample water b) Membrane filter c) Electronic weighing d) Filtration apparatus 
connected to a vacuum pump (Nalgene, U.S.A) e) Dry membrane filter

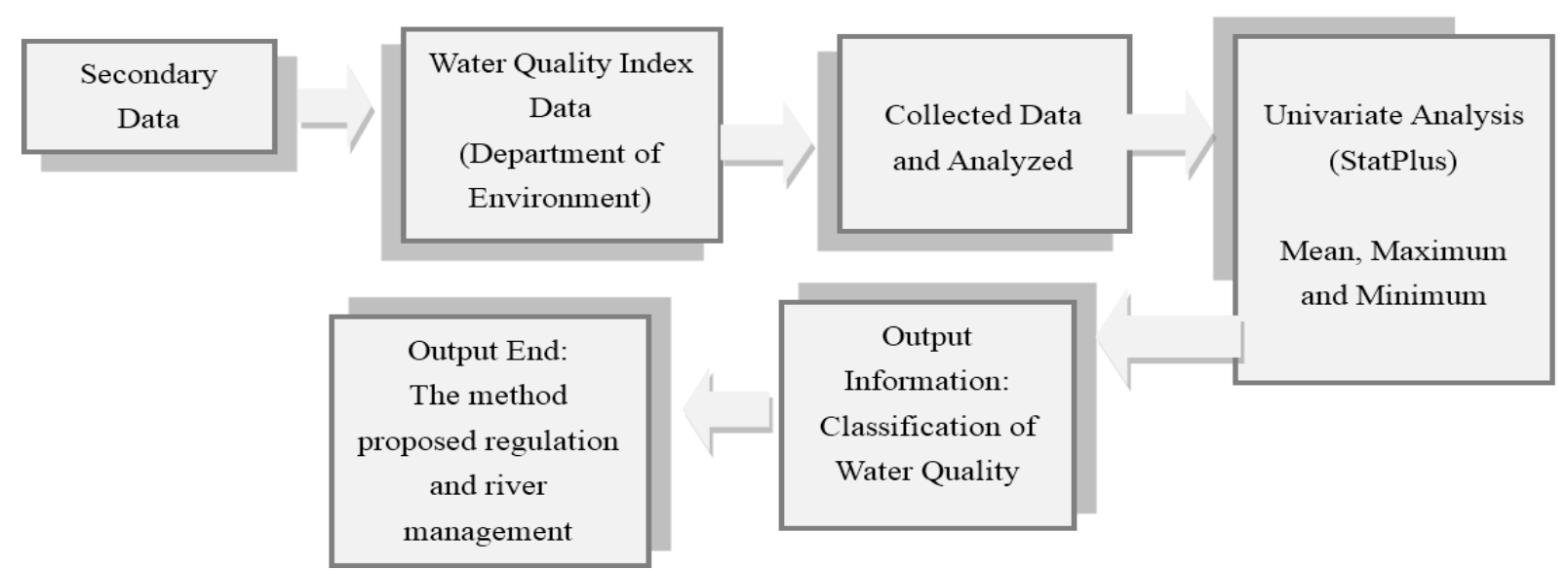

Fig.3. A framework for measurement of river WQI based on univariate analysis

\section{RESULTS AND DISCUSSION}

Based on this study, the threshold range of the DO for Malaysian surface water is from 3.0 to $5.0 \mathrm{mg} / \mathrm{L}$. Overall, the DO values of eight sampling stations at Klang River were high compared to Juru River. Klang River recorded between $2.76-5.71 \mathrm{mg} / \mathrm{L}$ classified as II to IV. The levels of DO at Klang River higher compared Juru River due to waste discharge from the industrial and residential development. All stations in this study recorded exceed of the permitted standards $(<5.0 \mathrm{mg} / \mathrm{L}) .1 \mathrm{~K} 40$ station contributed the lowest level of DO compared others stations at Klang River $(2.76 \mathrm{mg} / \mathrm{L})$. A sampling stations recorded minimum DO index in class IIB 1K46 station calculated the pollution levels in the context of DO is controlled. Juru River show a DO reduction in both sampling stations namely stations and 2JR12 2JR01 when recorded between 2.74mg/1-2.75mg/1 (Fig. 4). Generally, BOD, COD and DO needed in the process of respiration and decomposition of organic matter carried by aquatic plants in water.

A high level of organic pollution in the aquatic system will increase the BOD and COD concentrations and lower the concentration of DO. There are many anthropogenic and geomorphology factors which triggers the reduction of DO concentration in river. One of the main reason the reduction of DO concentration at Klang River is the production of sewage from commercial and domestic waste from residential areas nearby the Klang River [17]. The ratio of $\mathrm{BOD}$ and $\mathrm{COD}$ was calculated for each station as this ratio provides information with 
the extent of biodegradability of the organic matter in the study area [19]. This is because Klang and Petaling are two sub-areas of the river which focused on the development of land-use residential, industrial and business services located in Klang and Petaling [20]. Effect of changes of DO concentration in Juru River drainage also identified the same factors as the area is near two stations Perai Industrial area and residential population located near Bukit Mertajam.

Fig. 5 shows the BOD concentration at Klang River and Juru River where recorded 7.33 to $11.28 \mathrm{mg} / \mathrm{L}$ and 10.47 to $11.57 \mathrm{mg} / \mathrm{L}$ respectively, this BOD classified as class $\mathrm{III}$. All the sampling stations recorded maximum BOD index that exceed allowable standards of $>6 \mathrm{mg} / \mathrm{L}$. In addition, there was a general decreasing trend in the BOD and COD concentrations from downstream to upstream stations which recorded high concentrations for these two parameters at Klang River and Juru River. Generally, the BOD concentration is the total organic matter in water which can be decomposed by micro-organisms for the decomposition process requires oxygen. A lot of organic material that can be decomposed by microorganisms and more oxygen is used triggers the higher BOD concentration [21]. Based on NWQS classifications, the BOD concentrations for most of the stations were in Class III. BOD concentration is higher at Klang River and Juru River due to the influx of organic material stemming from domestic waste and rubbish as described previously.

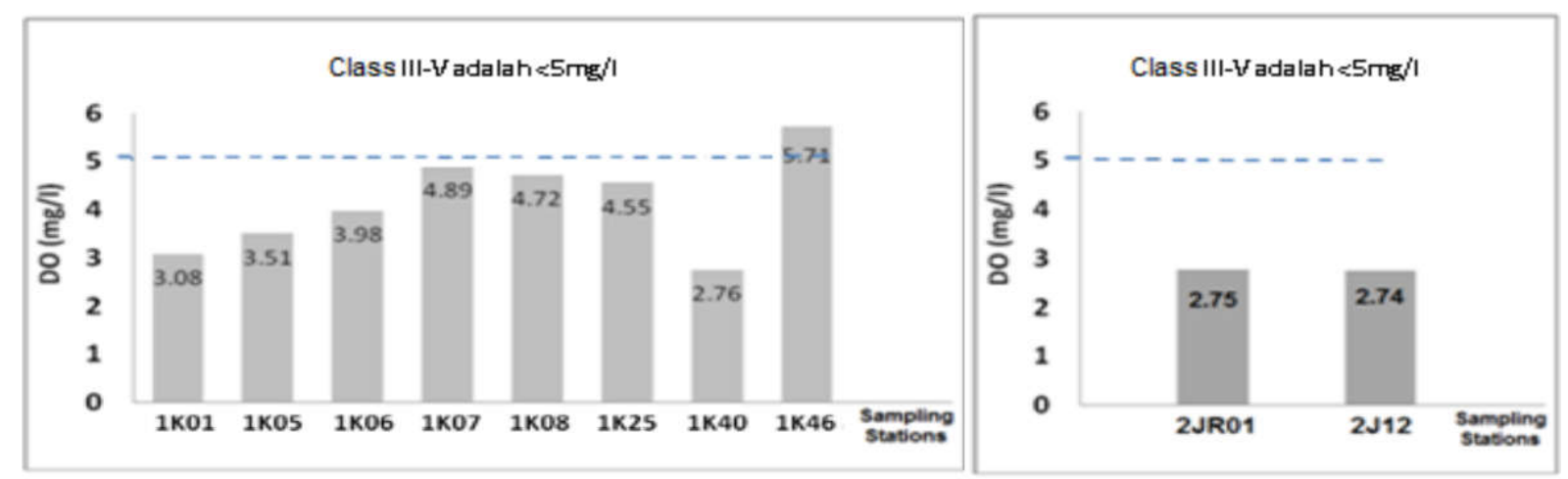

Fig.4. DO index in each of the sampling stations Klang River and Juru River 


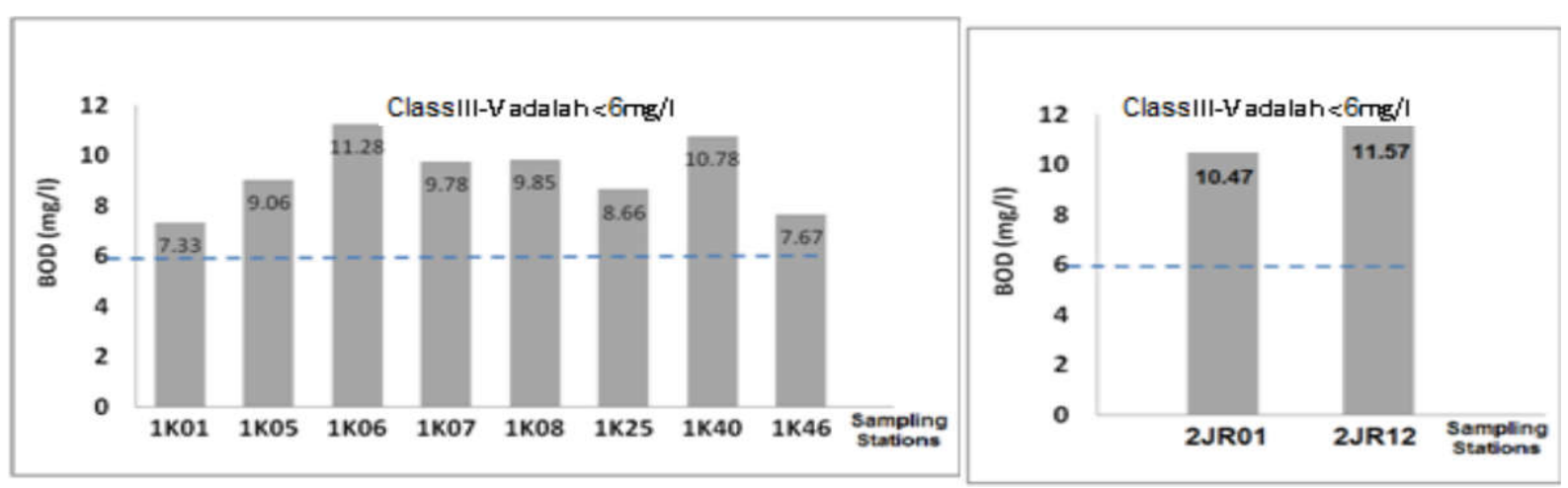

Fig.5. BOD index in each of the sampling stations Klang River and Juru River COD concentration at Klang River recorded between $22.74-32.5 \mathrm{mg} / 1$ were classified as class I to IIB (Fig. 6). This COD concentration level proved the Klang River Basin not really polluted, its COD concentration is not exceed the allowable standards (50mg/L). However, there are extensive treatments required. The management and control approach must be conducted to improve these problems before these issues become more serious as one of the conservation method. While, COD concentration at Juru River indicates the range between $37.95-38.18 \mathrm{mg} / 1$ in class IIB. Generally, COD is the amount of oxygen needed to allow the oxidation process of organic and inorganic substances in the water and of sewage and agro-based industries [22]. COD concentration higher than the BOD showed that most of the organic matter in the river consisted of inorganic materials that can also be oxidized, [23-24]. This means that the low COD concentration can be attributed to the presence of a higher amount of inorganic versus organic matter in all sub areas of Klang River and Juru River. In addition, the organic material is decomposed by oxidation by chemicals also cause the low DO concentration.

TSS concentration ranges at Klang River recorded between $27.42-154.17 \mathrm{mg} / \mathrm{L}$, which classified as class IIA and III. Station 1K01 showed the maximum SS index excess of the standards level $(150 \mathrm{mg} / \mathrm{L})$. However, Juru River recorded between $44.67-61.73 \mathrm{mg} / \mathrm{L}$ of TSS (Fig. 7). Many factors influenced the production of SS in river such as soil erosion due to unplanned land use development [25] natural processes such as erosion of bedrock and erosion of river bank [26]. The main factors caused the higher amount of SS concentration is sedimentation problem at downstream areas of the Klang River is likely due to the effect of tidal currents was caused the erosion bank. The sedimentation problems recorded higher at 
downstream area than upstream area [2]. At Klang River contributed SS production higher slightly from the middle stream due to urbanization development.
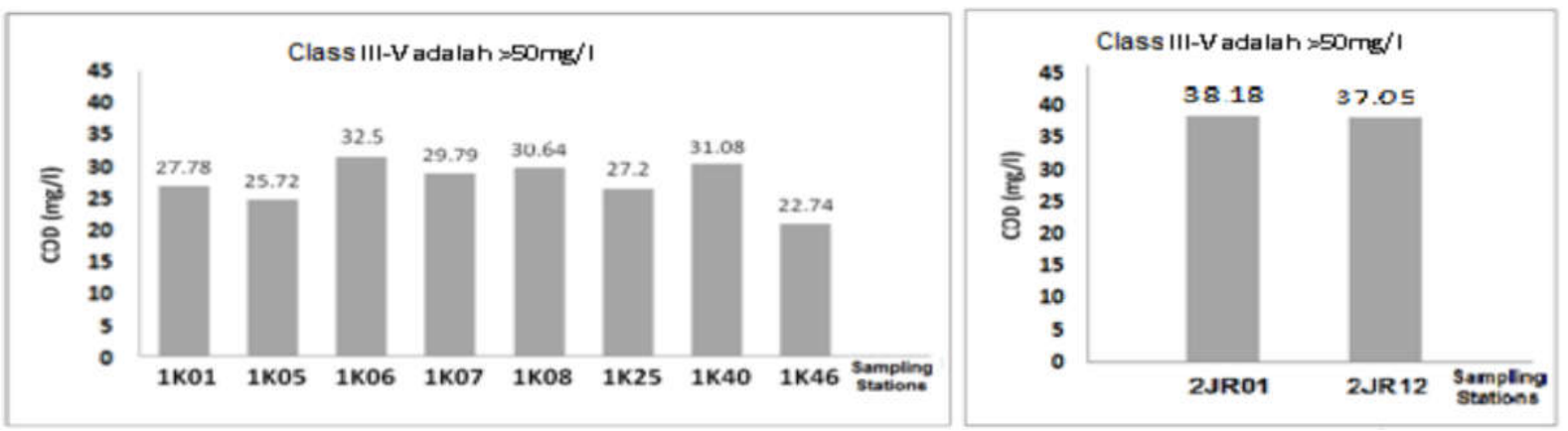

Fig. 6. COD index in each of the sampling stations Klang River and Juru River
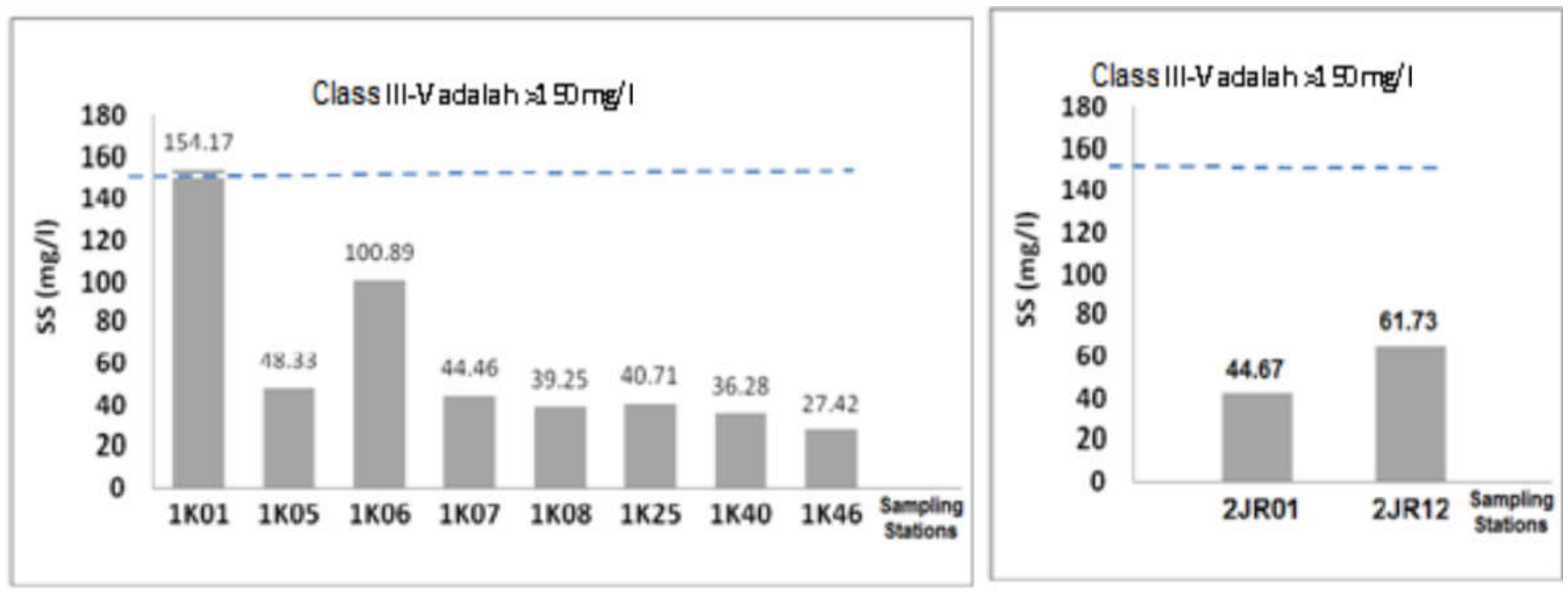

Fig. 7. TSS index in each of the sampling stations Klang River and Juru River

pH index ranges at Klang River point between 6.91-7.25 classified as class IIA-IIB (Fig. 8). The level of $\mathrm{pH}$ still under controlled, it is not exceeding the standard level (pH 5). The $\mathrm{pH}$ level at Juru River drainage showed as good level of alkalinity which recorded between 6.82-6.96 compared to Klang River. (Fig. 9) show the $\mathrm{NH}_{3}-\mathrm{NL}$ concentration at Klang River recorded between $2.00-4.97 \mathrm{mg} / 1$ which are classified as class III to V. The content of $\mathrm{NH}_{3}-\mathrm{NL}$ at Klang River Basin exceeds the standard level of $\mathrm{NH}_{3}-\mathrm{NL}(0.9 \mathrm{mg} / \mathrm{L})$. Juru River recorded between 3.63-4.76mg/L of $\mathrm{NH}_{3}-\mathrm{NL}$ has been classified as class V. Generally, the increasing of $\mathrm{NH}_{3}-\mathrm{NL}$ values as a result of the decomposition process such as the waste from human and animal's faces, agricultural, fertilizers, domestic sewage and industry [27-28]. The concentration of $\mathrm{NH}_{3}$-NL higher at Klang River and Juru River were triggers of determination by residential areas, industrial, agricultural, farming and business services. These factors 
caused the increasing of concentration of $\mathrm{NH}^{3}-\mathrm{NL}$ and positive correlated with $\mathrm{BOD}$ concentration due to the sewage production.

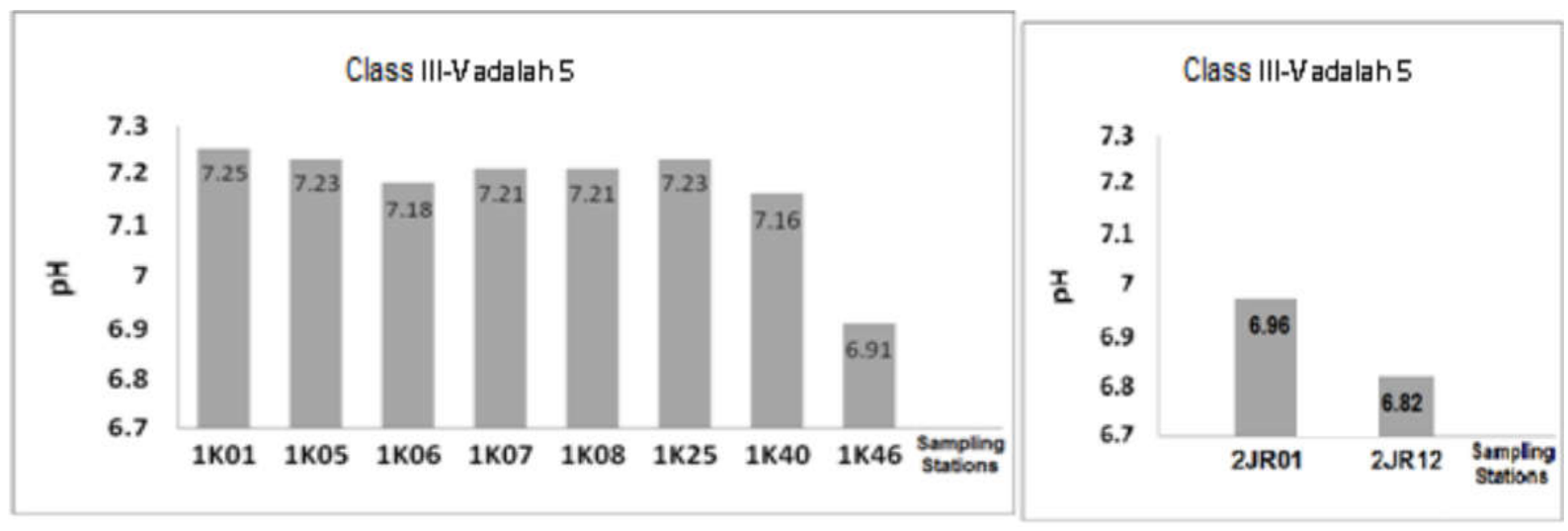

Fig.8. $\mathrm{pH}$ index in each of the sampling stations Klang River and Juru River
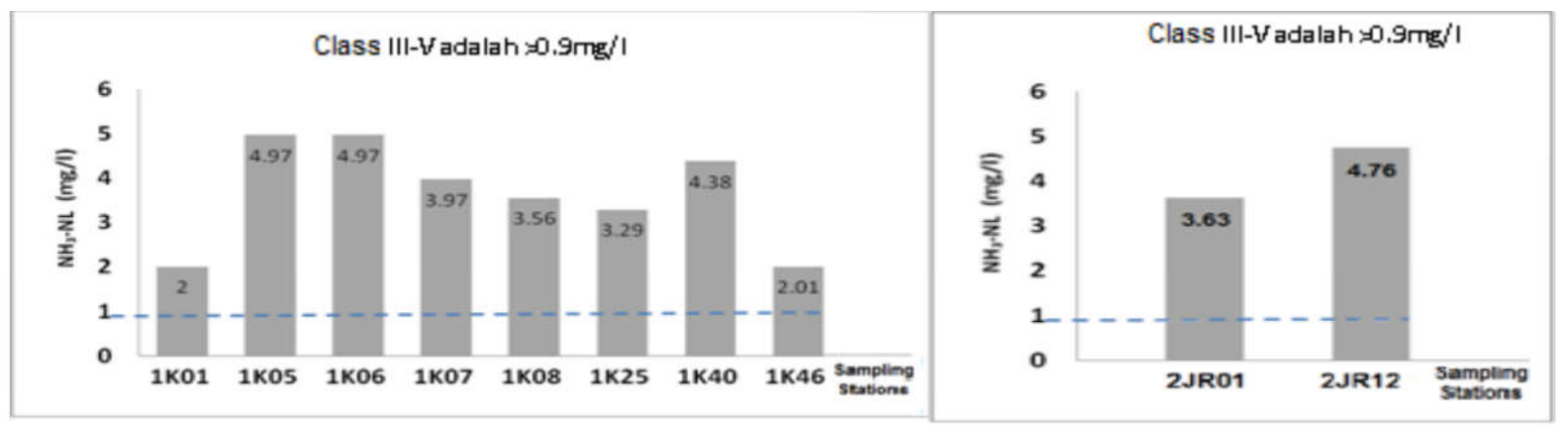

Fig.9. NH3-NL index in each of the sampling stations Klang River and Juru River

Based on the findings of a survey WQI in Klang River and Juru River, four water quality parameters such as DO, BOD, SS and NH3-NL have recorded that average air quality index is in excess of the permitted standards. WQI parameter ranges tested index shows the central region of Klang River having a source of water pollution in the area is higher than the downstream and upstream of Juru River while going upstream. Four water quality parameters that have been discussed are categorized as major pollution sources that contribute to the deterioration of water quality over the last five years (2009-2013). Therefore, it is undeniable that the main source of pollution in fact has to do with land-use residential, industrial and business services that run close to the sampling stations.

\section{CONCLUSION}

Klang River and Juru River has a sensitive water ecosystem were responds to the land use 
changes. The results of water quality trends clearly showed that most of the water quality parameters were slightly higher which classified as class III and class V. From the study, it is clear that station downstream and middle stream) more polluted than other sampling stations which mostly at upstream area due to land use activities such as land-use residential, industry, services and business has affected water quality index for each parameter. The preservation and conservation of the river as sustainable river management should be implemented. This is ensured to minimize the water quality deterioration at Klang River and Juru River.

\section{ACKNOWLEDGEMENTS}

The authors would like to acknowledge the Department of Environment, Ministry of Natural Resources and Environment Malaysia for their permission to utilize the water quality data and the financial support of Ministry of Higher Education Malaysia for funding this project (FRGS Project number: RR061). And to East Coast Environmental Research Institute (ESERI), Universiti Sultan Zainal Abidin (UNISZA) give permission to use research facilities and supporting in this research.

\section{REFERENCES}

[1] Department of Statistics, Malaysia (DSM). Annual report 2015. Putrajaya: DSM, 2015

[2] Kamaruddin A F, Toriman M E, Juahir H, Zain S M, Rahman M N, Kamarudin M K, Azid A. Spatial characterization and identification sources of pollution using multivariate analysis at Terengganu river basin, Malaysia. Jurnal Teknologi, 2015, 77(1):269-273

[3] Nasir A. H. Lembangan sungai dalam peradaban Melayu. Selangor: Universiti Kebangsaan Malaysia Press, 2005

[4] Lee M R, Fulazzaky M A. Assessment of Bekok River water quality status and its suitability for supporting the different uses: A review. International Journal on Advanced Science, Engineering and Information Technology, 2011, 1(6):672-674

[5] Aiyub K. Pencemaran air dan pengurusannya di Malaysia: Cabaran di alaf baru. In Pengurusan persekitaran di Malaysia: Isu dan cabaran. Selangor: Universiti Kebangsaan Malaysia Press, 2000, pp. 104-126

[6] Economic Planning Unit (EPU). Ninth Malaysia Plan, 2006-2010. Putrajaya: Prime 
Minister's Department, 2006

[7] Nayan N, Hashim M, Ibrahim M H, Che N M S Y. Perubahan gunatanah dan tahap kualiti air sungai di Bandaraya Ipoh, Perak. Malaysian Journal of Environmental Management, 2009, $10(2): 115-134$

[8] Wahab N A, Kamarudin M K, Gasim M B, Umar R, Ata F M, Sulaiman N H. Assessment of total suspended sediment and bed sediment grains in upstream areas of Lata Berangin, Terengganu. International Journal on Advanced Science, Engineering and Information Technology, 2016, 6(5):757-763

[9] Haslinur M D, Mohd E T, Mazlin M. Loading concentrations of pollutant in Alur Ilmu at UKM Bangi campus: Event Mean Concentration (EMC) approach. Malaysian Journal of Analytical Sciences, 2012, 16(3):353-365

[10] Dingman S. L. Physical hydrology. Illinois: Waveland Press, 2015

[11] Gasim M B, Toriman M E, Idris M, Lun P I, Kamarudin M K, Azlina A N, Mokhtar M, Mastura S S. River flow conditions and dynamic state analysis of Pahang River. American Journal of Applied Sciences, 2013, 10(1):42-57

[12] Jaafar M, Zainuddin M S, Syed A S M. Implikasi pembangunan bandar Indera Mahkota kepada pencemaran Sg. Talam, Kuantan, Pahang. Malaysian Journal of Society and Space, 2014, 10(3):201-213

[13] Department of Environment (DOE), Malaysia. Water quality report. Putrajaya: Ministry of Natural Resources and Environment, 2013

[14] Department of Environment (DOE), Malaysia. Malaysia environmental quality report. Putrajaya: Ministry of Natural Resources and Environment, 2015

[15] Ismail A, Toriman M E, Juahir H, Zain S M, Habir N L, Retnam A, Kamaruddin M K, Umar R, Azid A. Spatial assessment and source identification of heavy metals pollution in surface water using several chemometric techniques. Marine Pollution Bulletin, 2016, 106(1):292-300

[16] Municipal Council of Seberang Perai (MPSP). Draf rancangan tempatan daerah Seberang Perai Tengah 2020. Pulau Pinang: MPSP, 2015

[17] Hoo S H, Samat A, Othman M R. Indeks Kualiti Air Negara (IKAN) Sistem Sungai 
Labu. Malaysia Journal of Analytical Science, 2006, 10(1):7-14

[18] Kamarudin M K A, Toriman M E, Sharifah M S A, Idris M, Jamil N R, Gasim M B. Temporal variability on lowland river sediment properties and yield. American Journal of Environmental Sciences, 2009, 5(5):657-663

[19] Toriman M E, Yun L Q, Kamarudin M K A, Aziz N A A, Mokhtar N A A, Elfithri R, Bhaktiku K. Applying seasonal climate trends to agricultural production in Tanjung Karang, Malaysia. American Journal of Agricultural and Biological Sciences, 2014, 9(1):119-126

[20] Suratman S, Ali A, Ting L T. Penilaian indeks kualiti air di Lembangan Sungai Ibai, Terengganu. Sains Malaysiana, 2005, 34(2):55-59

[21] Mohamed A A, Rahim S A, Aitman D A, Kamarudin M K A. Analisis kandungan karbon organik tanah secara bermusim di hutan Bukit Jeriau, Fraser Hill, Pahang. Malaysian Journal of Analytical Sciences, 2016, 20(2):452-460

[22] Suratman S, Mohd Tahir N. Kesan antropogenik terhadap kualiti air di lembangan Sungai Marang. Perairan Selatan Laut China Selatan. Sains Malaysiana, 2013, 42(6):743-751

[23] Kamarudin M K A, Idris M, Toriman M E. Analysis of Leptobarbus hoevenii in control environment at natural lakes. American Journal of Agricultural and Biological Science, 2013, $8(2): 142-148$

[24] Chapman D, Kimstach V. Selection of water quality variables. In D. Chapman D (Ed.), Water quality assessments: A guide to the use of biota, sediments and water in environmental monitoring. Florida: CRC Press, 1996, pp. 59-126

[25] Lim S H, Abdullah S, Othman M R. Kesihatan ekosistem Sungai Labu dari aspek kualiti airnya. Malaysian Journal of Analytical Sciences, 2001, 7(1):157-168

[26] Toriman M E, Kamarudin M K A, Sansena T, Bhaktikuld K, Umar R, Muhamad A, Aziz N A A, Sulaiman N H. Assessment of land use change and sedimentation modelling on environmental health in Tropical River. Malaysian Journal of Analytical Sciences, 2015, 19:1335-1347

[27] Thuy N N, Hoang H A. Vulnerability of rice production in Mekong River Delta under impacts from floods, salinity and climate change. International Journal on Advanced Science, Engineering and Information Technology, 2015, 5(4):272-279

[28] Lee M R, Fulazzaky M A. Assessment of Bekok River water quality status and its suitability for supporting the different uses: A review. International Journal on Advanced Science, Engineering and Information Technology, 2011, 1(6):672-674. 


\section{How to cite this article:}

Zin MSM, Juahir H, Toriman ME, Kamarudin MKA, Wahab NA, Azid A.Assessment of water quality status using univariate analysis at klang and juru river, Malaysia. J. Fundam. Appl. Sci., 2017, 9(2S), 93-108. 